\title{
Efficiency in Internal Auditing: A Study of Turkish Public Administration
}

\begin{abstract}
Mustafa TAYTAK (https://orcid.org/0000-0002-0987-1123), Department of Public Finance, Uşak University,
\end{abstract} Turkey; e-mail: mustafa.taytak@usak.edu.tr

Murat AYDIN (https://orcid.org/0000-0002-7211-5208), Department of Accounting Information Systems, Uşak University, Turkey; e-mail: murat.aydin@usak.edu.tr

\section{İç Denetimde Etkinlik: Türk Kamu İdarelerinin İncelenmesi}

\begin{abstract}
With the development of the modern state approach, rational use of public resources has become particularly important for public institutions. In this context, the terms efficient, economical, and productive are considered important instruments in the effectiveness of public institutions. One of the necessary elements in the effectiveness of public institutions is the presence of an effective system of internal audit. The effectiveness of internal auditing generally depends on the existence of elements such as independence and impartiality of internal audits. In this study, internal audit perceptions of public servants who have financial responsibility were measured. Furthermore, the impact levels of elements that are effective in internal auditing were analyzed using the "Structural Equation Model." This model showed that the high level of perception of value added to internal auditing is the most important factor affecting effective internal audits.
\end{abstract}
Keywords $\quad$ : Internal Audit, Public Administration, Internal Audit System, International Internal Audit Standards, Structural Equation Modelling.

JEL Classification Codes : H61, H83, M42.

\section{Öz}

Modern devlet yaklaşımının gelişmesiyle, kamu kaynaklarının rasyonel kullanımı oldukça önemli hale gelmiştir. Bu bağlamda etkili, ekonomik ve verimli terimleri kamu kurumlarının etkililiğinde önemli araçlar olarak kabul edilmektedir. Kamu kurumlarının etkili olmasında gerekli unsurlardan birisi de etkin bir iç denetim sistemidir. İç denetimin etkin olması, genellikle iç denetimin bağımsızlığı ve tarafsızlığı gibi unsurların varlığına bağlıdır. Bu çalışmada, mali sorumluluğa sahip olan kamu görevlilerinin iç denetim algıları ölçülmüştür. Ayrıca, iç denetimde etkili olan unsurların etki düzeyleri "Yapısal Eşitlik Modeli" kullanılarak analiz edilmiştir. Bu model, iç denetimin kuruma kattığı değer algısının yüksek düzeyde olmasının, iç denetimleri etkileyen en önemli faktör olduğunu göstermektedir.

\section{Anahtar Sözcükler Iç Denetim, Kamu İdaresi, İç Denetim Sistemi, Uluslararası İç} Denetim Standartları, Yapısal Eşitlik Modeli. 


\section{Introduction}

In the last century, in parallel with the developments in the world, the importance of transparency in public administration, the rational use of public resources, the development of accountability, and the reduction of corruption in public administration have been important for auditing in public fiscal management. Moreover, an increase in the share of the public economy in the general economy shows that auditing is critical. A new audit approach has been introduced in Turkish public administration. With this law, new targets have been determined, such as strengthening previously performed external auditing and finding an application area in the public financial management process.

Effective and productive operation of internal audits, organized as part of an internal control system, will increase efficiency in public administration. Therefore, the question "How can an effective internal audit be established?" is the skeleton of our study. In this context, the factors that may determine the efficiency of internal auditing in our study were established based on the basic regulations and the definition of internal audit. These factors were determined to be the independence of internal audits, the neutrality of internal audits, the efficiency of internal audits, the support of top management for internal audits and the adding of value by internal audits to the studies of public administration.

The concepts of audit and internal audit, whose importance has increased more in recent years in public administrations, were the initial focus of the study. Then, the studies on internal audit were evaluated within the scope of the purpose, method and results, and a table was prepared within the framework new literature model ${ }^{1}$ and they were presented to the reader. The reasons why internal auditing is necessary were mentioned by discussing the factors which are produced within this study and required for an effective internal audit, and in this context the fundamental hypotheses of this study were developed. In the last part, how the factors which would make the internal audit effective were perceived, and how this perception affected internal audits were analyzed through structural equity modelling. Accordingly, the impact levels of these factors from lowest to highest were determined and the recommendations for an effective internal audit were presented.

\section{Internal Auditing in Turkish Public Administrations}

Internal auditing, which is an important element of the audit process in the public sector, was first introduced to our legislation in 2005. Internal auditing has a legal framework at the first, second and third levels. 
Table: 1

The Place of Internal Audit in The Legislation

\begin{tabular}{|l|l|}
\hline \multicolumn{1}{|c|}{ Primary Legislation } & \multicolumn{1}{c|}{ Secondary Legislation } \\
\hline * Public Finance Management And Control Law & $\begin{array}{l}\text { * Implementing Regulation on Working Procedures and Principles } \\
\text { of Internal Audit Coordination Board }\end{array}$ \\
\hline $\begin{array}{l}\text { * Law No. 5436 on the Amendment of the Public Financial Management and } \\
\text { Control Law and Certain Laws and Decree Laws }\end{array}$ & $\begin{array}{l}\text { * By-Law on The Working Procedures and Principles of Internal } \\
\text { Auditors }\end{array}$ \\
\hline
\end{tabular}

Internal auditing is one of the two components of the pre-audit. Accordingly, an internal audit is an independent, objective (neutral) assurance and consultancy service performed in order to guide and evaluate whether the resources for adding value to the activities in public administration and developing them are administered in accordance with economy, efficiency and productivity. In addition, it was stated in related law that an internal audit would be implemented by internal auditors, and that they would be charged by the Coordination Board of Internal Audit. Here, another important point is that internal auditing is at the initiative of executives. In other words, internal auditing is not compulsory, and it is an establishment appointed by the Coordination Board of Internal Audit if requested by the executives. Basic provisions concerning internal audits are regulated by the law numbered 5018, and detailed information on internal auditing is regulated by the "Regulation of Working Procedures and Principles of Internal Auditors." According to the related regulation, internal auditors carry out internal audit activities with five different audit types. These audit types are indicated in Figure 1.

\section{Figure: 1 \\ Internal Audit Types}

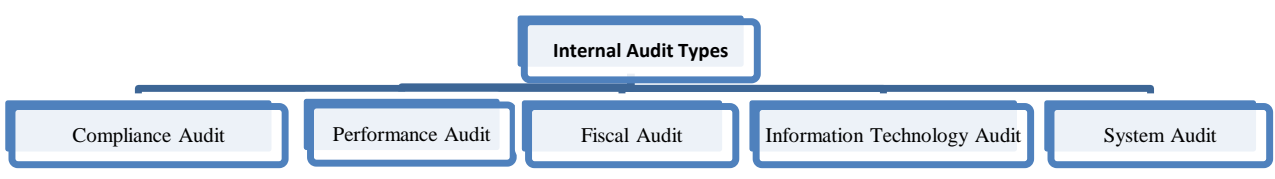

The most common audit type encountered in practice is the conformity audit. A conformity audit is an audit type performed essentially after expenses. Conformity audit has been defined in the regulation as "the conformity analysis of public administration activities and transactions to the relevant laws, constitutions, regulations and other legislations." However, the European Commission determined that conformity audits are conformity checks of the organization to laws, constitutions, regulations and preestablished principles. Performance audits are the most emphasized type of audit in Law No. 5018 due to the fact that they are essential for effective, economic and productive use of public resources. This new understanding in the law necessitates the performance audit. Again, in the same regulation, performance audits were defined as the evaluation of efficiency, economy and productivity in the planning, practicing and control stages of the activities and transactions performed in all stages of administration. In other words, a performance audit is for testing the performance of an institution against preestablished standards. 
However, financial auditing is for the evaluation of the accuracy of accounts and transactions regarding incomes, assets and obligations and the reliability of a financial system and statements. The first stage of financial auditing is the accounting audit. The competence of an accounting system and the accuracy and conformity to laws, constitutions and regulations of financial transactions are analyzed in this part (Bayar, 2008:155). System auditing is the analysis of the activities of the audited unit and the internal control system with a contributing approach to the organizational structure, identifying the deficiencies, investigating the quality and conformity, and measuring the adequacy of the resources and the applied methods. The final audit type by internal auditors is the information technologies audit. An information technologies audit is the evaluation of the continuity and reliability of the electronic information systems of the audited unit.

\section{Literature Review}

In the study, the literature was reviewed as specific to internal audits in public administration. In this context, various national and international sources were included. A part of the sources in the literature review was used in other parts of the study. In the study, the $4 \mathrm{~W} 1 \mathrm{H}$ literature scanning model was used.

\subsection{Theoretical Literature}

How the public resources of the Turkish public financial administration system were used could be observed by the establishments such as investigation and inspection before the Law numbered 5018 (Okur, 2010: 570-586). Internal audit is a concept which has only been included in our financial administration system since 2005. Most of the studies in the national literature belong to the year 2005 and later. In a study conducted in 2006, it was stated that the Law of Public Accounting numbered 1050 was insufficient and a new law was necessary (Kolçak, 2006, 367-384). Advantages of the new Law for the Turkish financial system were discussed. In a study titled 'Internal Audit in Public' conducted in 2007 (Korkmaz, 2007), internal auditing was explained in detail. Important issues such as the definition of internal audit, its relation to external audit, its difference from the existing understanding of audits, and the final status of internal auditing were included in this study. Some other studies in the literature examined other issues, such as the relationship between internal audit and internal control, how and to what extent they affect each other (Uzun, 2009: 59-65), and why internal audit systems should be improved for a quality internal audit (Memiş, 2008: 75-91).

In his study, Kesik (2005) focused on the concepts of internal audit and internal control by handling the necessity of the Law numbered 5018 from the point of view that public expenses had a continuous increase. Akyel (2010), who approached the subject from the same perspective, stated in his study that it was necessary to build internal control and internal auditing on solid ground for good public financial administration. In a study, Arslan (2010) evaluates the internal audit as a function which strengthens the success, reliability and accountability of the executives in institutions, and its increasing importance on a day to day basis. In this context, he mentions that many countries have legalized the internal 
audit in both the private sector and public administration. In his study 'From Management Audit to Audit Management', Kuluçlu (2006) focused on the concepts of audit and administration and stated that audit would not be independent from administration and that questioning the legitimacy of administrators' activities was an important achievement for individuals. Başpınar (2006), stated in his study that the internal audit is handled seriously in European public administrations and its practice in Turkey is essentially an institution enacted during the adaptation process to the European Union. In one of his studies, Sahin (2008) mentioned the importance of internal auditing, and stated that this had an important role in the adaptation to the European Union and that the issues concerning internal audits were regulated in the 32nd paragraph under the title of "Financial Control" within the adaptation process. Bozkurt (2010) made evaluations reflecting general acceptance and consensus regarding the nature of good financial administration and what it would be like based on the framework of the Law of Public Financial Administration and Control. In this study, it was stated that top managers of public administrations were the main actors in internal control and related internal auditing.

\subsection{Methodological Literature}

Table: 2

Literature Review of Internal Audit

\begin{tabular}{|c|c|c|c|c|}
\hline Author & Date & Aim of Study & Method & Result \\
\hline $\begin{array}{l}\text { Guthrie, J., } \\
\text { English, L. }\end{array}$ & 1997 & $\begin{array}{l}\text { The aim of the study was to measure the } \\
\text { performance of the recent fiscal reforms } \\
\text { in the public sector in Australia. }\end{array}$ & * Document Review & $\begin{array}{l}\text { Reforms for performance measurement in the } \\
\text { public sector were not effective. }\end{array}$ \\
\hline $\begin{array}{l}\text { Brierley, J.A., } \\
\text { El-Nafabi, H.M., } \\
\text { Gwilliam, D.R. }\end{array}$ & 2001 & $\begin{array}{l}\text { The aim of this study was to investigate } \\
\text { the reasons for not having established } \\
\text { internal auditing in the public sector in } \\
\text { Sudan. }\end{array}$ & $\begin{array}{l}* \text { Depth Interview } \\
* \text { Direct Observation }\end{array}$ & $\begin{array}{l}\text { The reasons why an internal audit institution } \\
\text { could not be established in the public sector in } \\
\text { Sudan; } \\
\text { * Political Instability } \\
\text { * Economic Recession } \\
\text { * Lack of Education }\end{array}$ \\
\hline $\begin{array}{l}\text { Subramaniam, N., } \\
\mathrm{Ng}, \mathrm{C} . \text {, } \\
\text { Carey, P. }\end{array}$ & 2004 & $\begin{array}{l}\text { The aim of the study was to demonstrate } \\
\text { the extent of outsourcing internal } \\
\text { auditing in Queensland, Australia. }\end{array}$ & * Document Review & $\begin{array}{l}\text { In the study, it was found that there was } \\
\text { comprehensive outsourcing in the public sector } \\
\text { in the state of Queensland. }\end{array}$ \\
\hline $\begin{array}{l}\text { Carcello, J.V., } \\
\text { Hermanson, D.R., } \\
\text { Raghunandan, K. }\end{array}$ & 2005 & $\begin{array}{l}\text { The aim of this study was to measure the } \\
\text { effects of US public companies' budget } \\
\text { investments on internal auditing and on } \\
\text { factors such as company size, financial } \\
\text { leverage, and the relative amount of } \\
\text { inventory. }\end{array}$ & $\begin{array}{l}\text { * Survey } \\
\text { - A questionnaire was } \\
\text { applied to the chief auditors } \\
\text { working in } 217 \text { public } \\
\text { companies. }\end{array}$ & $\begin{array}{l}\text { As a result, it was stated that the investment of } \\
\text { public companies in internal auditing had a } \\
\text { positive relationship with other factors. }\end{array}$ \\
\hline $\begin{array}{l}\text { Sterck, M., } \\
\text { Bouckaert, G. }\end{array}$ & 2006 & $\begin{array}{l}\text { The aim of the study was to reveal the } \\
\text { legal status, functioning and possible } \\
\text { future problems of internal auditing and } \\
\text { internal control systems of public in } 6 \\
\text { OECD member countries. }\end{array}$ & $\begin{array}{l}\text { * Document Review } \\
* \text { Depth Interview }\end{array}$ & $\begin{array}{l}\text { It was revealed that countries have similar } \\
\text { internal auditing in terms of legal and } \\
\text { organizational forms. However, it was } \\
\text { determined that some legal regulations are } \\
\text { needed for the independence of internal } \\
\text { auditing. }\end{array}$ \\
\hline $\begin{array}{l}\text { GetieMihret, D., } \\
\text { WondimYismaw, } \\
\text { A. }\end{array}$ & 2007 & $\begin{array}{l}\text { The aim of the study was to identify the } \\
\text { factors affecting the effectiveness of } \\
\text { internal audit services in the public } \\
\text { sector in Ethiopia. } \\
\text {-Quality of Internal Audit } \\
\text {-Management Support } \\
\text {-Organization Statement } \\
\text {-Relationship Between Factors }\end{array}$ & * Case Study & $\begin{array}{l}\text { In the study, it was determined that the theme of } \\
\text { the internal audit in the Ethiopian public sector } \\
\text { affected its quality, and other factors did not } \\
\text { have the same effect. }\end{array}$ \\
\hline $\begin{array}{l}\text { Ahmad, N., } \\
\text { Othman, R., } \\
\text { Othman, R., } \\
\text { Jusoff, K. }\end{array}$ & 2009 & $\begin{array}{l}\text { The study aimed to investigate the } \\
\text { effectiveness of internal auditing in the } \\
\text { Malaysian public sector. The survey } \\
\text { was conducted with internal auditors } \\
\text { and internal auditors working in } \\
\text { Malaysian public institutions. }\end{array}$ & * Survey & $\begin{array}{l}\text { The participants stated that they could not have } \\
\text { enough contact with their top managers. It was } \\
\text { determined that the personnel working in the } \\
\text { internal audit unit also do not have sufficient } \\
\text { knowledge. }\end{array}$ \\
\hline
\end{tabular}




\begin{tabular}{|c|c|c|c|c|}
\hline Gürkan, N.Z. & 2009 & $\begin{array}{l}\text { The aim of this study was to identify the } \\
\text { problems experienced in internal audit } \\
\text { units in Turkey and all relevant } \\
\text { information. }\end{array}$ & $\begin{array}{l}\text { * Survey } \\
\text { *Depth Interview } \\
\text { - The sample included } \\
\text { internal auditors, public } \\
\text { officials and bureaucrats. }\end{array}$ & $\begin{array}{l}\text { Internal audit implementation problems were } \\
\text { put forward and some suggestions were } \\
\text { presented. }\end{array}$ \\
\hline $\begin{array}{l}\text { Koçak, S., } \\
\text { Kavakoğlu, T. }\end{array}$ & 2010 & $\begin{array}{l}\text { The aim of this study was to measure the } \\
\text { internal audit Turkey employee } \\
\text { perceptions of internal auditors in the } \\
\text { provincial government. }\end{array}$ & $\begin{array}{l}\text { * Survey } \\
* \text { The questionnaires were } \\
\text { applied to } 45 \text { internal } \\
\text { auditors in } 18 \text { Special } \\
\text { Provincial Administrations. }\end{array}$ & $\begin{array}{l}\text { In this study, it was observed that there was no } \\
\text { communication between the internal auditor and } \\
\text { the top manager, and that the top managers did } \\
\text { not have enough information about the internal } \\
\text { audit. }\end{array}$ \\
\hline Aikins, S.K. & 2011 & $\begin{array}{l}\text { In the study, the effect of internal } \\
\text { auditing on financial performance in } \\
\text { local governments was investigated in } \\
\text { the United States. }\end{array}$ & $\begin{array}{l}\text { * Survey } \\
* \text { The questionnaires were } \\
\text { distributed to the chief } \\
\text { auditors in the local } \\
\text { administrations. }\end{array}$ & $\begin{array}{l}\text { The results showed that local government } \\
\text { auditors exerted more control in operational } \\
\text { areas, significantly affected the internal } \\
\text { performance of internal auditors, internal } \\
\text { controls and internal efficiency, and directly and } \\
\text { indirectly affected the financial performance of } \\
\text { local governments. }\end{array}$ \\
\hline Akçay, S. & 2013 & $\begin{array}{l}\text { The purpose of this study was to measure } \\
\text { the impact of internal auditing on the } \\
\text { results of public institutions in Turkey's } \\
\text { municipalities. }\end{array}$ & $\begin{array}{l}* \text { Survey } \\
\text { The survey was applied to } \\
110 \text { internal auditors } \\
\text { working in different } \\
\text { municipalities. }\end{array}$ & $\begin{array}{l}\text { It was determined that the internal auditors were } \\
\text { appointed without considering their adequacy; } \\
\text { additionally, it was revealed that internal audit } \\
\text { activity contributes to the efficiency of the } \\
\text { institution. }\end{array}$ \\
\hline $\begin{array}{l}\text { Enofe, A.O., } \\
\text { Mgbame, C.J., } \\
\text { Osa-Erhabor, } \\
\text { V.E., } \\
\text { Ehiorobo, A.J. }\end{array}$ & 2013 & $\begin{array}{l}\text { This study aimed to measure the } \\
\text { effectiveness of internal auditing in } \\
\text { public administrations in the province of } \\
\text { Edo in Nigeria. }\end{array}$ & $\begin{array}{l}* \text { Statistical Analysis } \\
* \mathrm{Z} \text { - Test }\end{array}$ & $\begin{array}{l}\text { It was concluded that effective governance can } \\
\text { only take place with the local government, } \\
\text { internal auditing plays a role in public financial } \\
\text { management, and internal auditing is not } \\
\text { effective in Edo province. }\end{array}$ \\
\hline $\begin{array}{l}\text { Tabak, A., } \\
\text { Erkuş, A. }\end{array}$ & 2014 & $\begin{array}{l}\text { The aim of the study was to measure the } \\
\text { response of individuals with internal } \\
\text { locus of control to individuals with } \\
\text { external locus of control in Turkey. }\end{array}$ & $\begin{array}{l}\text { * Survey } \\
\text { - } 444 \text { people working in } \\
\text { various public institutions } \\
\text { were administered the } \\
\text { "Internal-External Locus of } \\
\text { Control Scale". }\end{array}$ & $\begin{array}{l}\text { The responses of the participants to change were } \\
\text { measured by "Tolerance to Uncertainty Scale." } \\
\text { Accordingly, it was determined that the } \\
\text { tendency to tolerate the uncertainty of the } \\
\text { individuals who are focused on internal audit is } \\
\text { higher than those focusing on external audit. }\end{array}$ \\
\hline Kaya, K. & 2016 & $\begin{array}{l}\text { The aim of the study was to examine the } \\
\text { internal auditing practice in public } \\
\text { institutions in Turkey. }\end{array}$ & $\begin{array}{l}\text { * Survey } \\
- \text { A questionnaire was } \\
\text { distributed to } 50 \text { internal } \\
\text { auditors working in } 12 \\
\text { different public institutions. }\end{array}$ & $\begin{array}{l}\text { It was concluded that internal auditing in public } \\
\text { institutions has a number of shortcomings. Some } \\
\text { suggestions were made at the end of the study. }\end{array}$ \\
\hline $\begin{array}{l}\text { Udeh, S.N., } \\
\text { Nwadialor, E.O. }\end{array}$ & 2016 & $\begin{array}{l}\text { The aim of the study was to measure the } \\
\text { effectiveness of internal auditing in } \\
\text { Nigerian public administrations. }\end{array}$ & $\begin{array}{l}\text { * Survey } \\
\text { *Depth Interview } \\
* 127 \text { accountants and } 51 \\
\text { internal auditors were } \\
\text { included. }\end{array}$ & $\begin{array}{l}\text { It was determined that internal auditing was not } \\
\text { fully implemented, and that the rules of internal } \\
\text { auditing were violated in Nigerian public } \\
\text { administrations. There was no effective internal } \\
\text { auditing in Nigerian public administrations. }\end{array}$ \\
\hline
\end{tabular}

\section{Factors Affecting Internal Auditing and Hypotheses}

The factors which determine the efficiency of internal auditing are the international internal audit standards that the institutions are obliged to comply with in conducting the internal audit activities and the in-house application of the related institution to the internal audit (Uzun, 2009: 63). In this context, the factors for determining the efficiency of internal audits were identified based on international internal audit standards, basic legislation in Turkey concerning internal audits, and most of all, the definition of internal audit. Therefore, four main factors were determined regarding the efficiency of internal audits. These factors were determined to be the independence of internal audits, the neutrality of internal audits, executive support of internal audits, and adding value by internal auditing to the studies of public administration. The efficiency of internal audits should be considered a dynamic process which is continuously shaped by the interaction between the four factors above. This is due to the fact that internal auditing is a continual process that is conducted to do the right things continuously, not until the defaults are corrected. Each of the selected factors are discussed in detail below. 


\subsection{Independence of Internal Audits}

In the Institute of Internal Auditors study of 2016 titled 'International Standards for Professional Applications of Internal Audit,' the focus was on the independence factor which was necessary for an effective internal audit. Examining this study, it stated that independence was one of the important factors of internal auditing and that it was necessary to perform internal audit activities independently. Therefore, according to this study, internal auditors must be objective while performing their work. In addition, the independence of internal audits is defined as the fact that the internal auditing is free of conditions that threaten its ability to meet its responsibilities objectively.

There is no agreed definition regarding the independence of internal audit/auditor in literature. It can be said that the indicators or components of independence were emphasized instead. Accordingly, internal auditors having the opportunity to reach executives (or administration) and the board directly and limitlessly is indicated among the most important indicators of independence factor which are necessary to meet the responsibility of internal audit activities effectively (IAA, 2016: 5). Also, the easy accessibility of internal auditors to employees and in-house units is stated as an indicator of independence. Another indicator of independence is the freedom of internal auditors to think independently about all issues while performing their auditing tasks. Accordingly, for an independent internal audit, internal auditors can thoroughly act independently and objectively from the administration in all stages of the internal audit without prejudice (Çalış, 2013: 27).

Examining the results of some research on internal auditing, we can see that it was indicated how necessary the independence factor was in internal auditing for an effective internal audit. For instance, in one of Van Peursem's (2005) studies, based on interviews with internal auditors working in Australia, it was concluded that an audit conducted independently from the administration was a dominant characteristic for a successful audit. Similarly, in a study by Clark et al. (1981), it was also determined that the level of authority for the independence of internal auditing and reporting of the employees of the institution were the two most important factors affecting the objectivity of internal auditing. In this context, the organizational independence of internal auditing will increase the efficiency of internal auditors. The independence of internal auditing reduces conflict between internal auditors and administrators and provides a supportive working environment for auditors to perform their jobs objectively and without pressure. (Cohen \& Sayag, 2010: 300). In this context, the evaluation of the data and the making of recommendations about the data obtained by internal auditors from audits depends on the fact that it can be completely independent from the administration without any influence at every stage of the process.

Therefore, the first hypothesis of the study can be formulated as the following:

\section{H1. An effective internal audit depends on a high level of independence.}




\subsection{Objectivity of Internal Audits}

In application, independence and neutrality are often confused with each other, and these terms are used interchangeably by many people. However, independence and neutrality are not the same things. An individual can be independent while not being neutral, or in contrast, another can be neutral while not being independent. Understanding the difference between the two terms and knowing how the threats and insurances are influenced are important.

The concept of independence is usually described with real issues such as organizational positioning of internal audit activities, reporting relationships with members of the board, a different audit committee from the board, and access authorities to information, people and records. However, neutrality generally depends on the mental state of internal auditors, auditors' decisions, prejudices, relationships and behaviors (IIA, 2011: 4). According to international internal audit standards, internal audit activity should be independent and internal auditors should be neutral and unprejudiced while performing their jobs. Accordingly, neutrality is an objective mental attitude which allows internal auditors to perform their audit tasks believing in the outcome of their work and without sacrificing quality. Neutrality requires internal auditors to judge without depending on the opinions of others (IIA, 2016: 24).

In a study prepared by the research unit of the Institute of Internal Auditors in 2011, the factors affecting the neutrality of internal auditing were investigated. In this study, the factors affecting the neutrality of internal auditing were categorized under nine different titles: social pressure; economic interests; personal relationships; sincerity; cultural, racial and sexual prejudices; cognitive prejudice; personal interpretations; threat of fear; and threat of defence (Mutchler, 2001: 251; IIA, 2011: 7-8). The effects of these factors on both internal auditors and internal audit activities should be considered by executives. In this context, it is necessary to provide the essential environment to enable internal auditors to work without sacrificing the quality of the audit and without being influenced by others' ideas and suggestions (Kızılboğa, 2013: 117).

Therefore, the second hypothesis of the study can be formulated as the following:

\section{H2. An effective internal audit depends on a high level of neutrality.}

\subsection{Support by Executives}

One of the important factors which determines the efficiency of internal auditing is the support provided by executives to an institution's internal auditing and auditors. Establishing a strong and constructive relationship between the institution's internal audit unit and its executives should be considered an important factor for performing effective internal audits. In this context, in order to perform more effective internal audits, executives should provide sufficient and convenient support to the internal audit unit for realizing organizational efficiency and targets. 
Executive support for internal auditing and auditors is a significant sign for determining the role and efficiency of internal auditing in an institution. This support is an extra asset for internal auditors in performing their tasks and responsibilities. Based on their detailed literature review, Fernandez and Rainey (2006) argued that internal audit units having executive support had an important role in the organizational innovation of the institution. Similarly, in a study of internal auditors in Australia, Leung et al. (2004) stated that internal auditors regarded themselves to be an important part of the management team, and believed that they could affect management decisions. Importantly, they considered the most significant underlying factor for this thought to be the support of executives. Van Gansberghe's (2005) study on four countries (Kenya, Uganda, Malawi, and Ethiopia) stated that executives needed to accept and appreciate the audit results so that the contribution and value of internal auditing to institutions would be efficient, and in the case of the lack of such support, the efficiency of internal auditing would be negatively affected.

Therefore, the third hypothesis of the study can be formulated as the following based on the previous studies:

\section{H3. An effective internal audit depends on the support level of top management for internal audit units.}

\subsection{Value Added of Internal Audits}

Internal auditing is an independent, objective insurance and consultancy activity designed to improve the activities of an institution and add value to them. Internal audits help an institution reach its targets by suggesting a systematic and disciplined approach for evaluating and improving the efficiency of its risk management, control, and governance processes (IIA, 2016: 23-26). Internal audits can only add value to the institution when its strategies, targets, and risks are considered. Therefore, an internal audit manager must effectively manage an internal audit so as to add value to the institution. It can be said that internal auditing is managed effectively when:

- It reaches the targets and responsibilities set in internal audit regulations,

- It is performed in accordance with international standards,

- Internal auditors indicate that they are in harmony with ethical rules and standards,

- They consider the tendencies to influence the institution and the new issues (IIA, 2016: 10).

Therefore, one of the main purposes of an internal audit is to create an internal auditor who integrates with the institution for increasing the quality of service, so that the institution becomes more functional and has an internal audit culture which operates for common purposes. In this context, performing audit activities within an audit philosophy which is not a rival to management, which acts together with management, which does not feel itself superior to management, and which adds value to the institution are regarded among the main purposes (Gönülaçar, 2007: 43). 
Therefore, the fourth hypothesis of the study can be formulated as the following:

\section{H4. An effective internal audit depends on the value-added level of an internal audit unit to an institution.}

\section{Analysis and Findings}

The purpose of this study is to measure the internal audit perceptions of public officials who have both accountabilities according to the Law numbered 5018 and financial liability to the Turkish Chamber of accounts. In this context, the extent of the research consists of public officials who have the responsibility for effective, economic and productive use of public resources as 'Executives, Spending Authorities, implementation officials and Accounting Authorities' working in public institutions.

The study was conducted in public administrations under the general budget, public administrations under special budget and 21 different public institutions under the budgets of local government. The study's data was collected by distributing survey forms to 386 people through the convenience sampling method. The collected data was analyzed using SPSS 18 and Lisrel 8.51 programs in order to identify the internal audit perceptions of public officials with financial liabilities. Structural equation modelling was used in the study.

\subsection{Reliability and Compliance Analysis}

Cronbach alpha coefficient and reliability of the scales were identified in the study.

Table: 3

\section{Reliability Analysis}

\begin{tabular}{|c|}
\hline Örneklem: 386 \\
\hline Questions Mean Minimum Maximum Range Max./Min. \\
\hline 3.7193 .1663 .9790 .8131 .257 \\
\hline Reliability Coefficient : 20 \\
\hline Reliability Alpha Coefficient $=\mathbf{0 . 7 1 1}$ Standart Alpha Coefficient $\mathbf{= 0 . 7 1 9}$ \\
\hline
\end{tabular}

Alpha coefficient for the scale is 0.711 and the standardized one is 0.719 . In this case, the scale used in the study is considered reliable. In addition, in order to present the accuracy of the data for the structural equation modelling, Explanatory Factor Analysis (EFA) and Confirmatory Factor Analysis (CFA) were conducted. In this context, the results obtained are indicated in the following tables respectively.

Table: 4

\section{Exploratory Factor Analysis}

\begin{tabular}{|lll|}
\hline KMO and Bartlett Test & & \\
\hline Kaiser-Meyer-Olkin Sample Proficiency Test & Approx.Chi-Square & 0.713 \\
\hline Bartlett Globality Test & Df & 1380 \\
\hline & Sig (Possibility) & 190 \\
\cline { 2 - 3 } & .000 & \\
\hline
\end{tabular}


When Table 4 is analyzed, we can see that the KMO coefficient is 0.713 . In this context, it is understood that the obtained results are sufficiently convenient for the related study. For that reason, sampling size in the study is sufficient. In addition, since $\mathrm{p}$ (possibility) value $=0.0000<0.01$, the significant Bartlett Globality Test result indicates the applicability of the factor analysis and the presence of the correlation and covariance between the variables.

The evaluation of compliance may vary according to the statistics package program used in confirmatory factor analysis (CFA). However, the statistics which have been most commonly used for determining the significance between the observed data matrix and the expected data matrix since the beginning of structural equation modelling studies and can, in a sense, be identified as the starting compliance value is the Chi-square $(\chi 2)$ test (Sümer, 2000). According to Hair et al. (2009), the Chi-square value is by itself insufficient to make the model valuable. Since Chi-square is sensitive to the sampling size, it loses its reliability particularly in cases where the sampling size is over 200 (in this study there are 386 samplings). Therefore, while evaluating whether the model is valid or not, analyzing the models out of Chi-square or other compliance indices will increase the reliability of the study.

Consequently, the test statistics used while evaluating the compliance between the data and the model in structural equation modelling are X2/sd (Chi-Square), goodness of fit and Root Mean Square Error of Approximation (RMSEA). The results obtained in order to present the compliance between the data we obtained from our study and the model are indicated in Table 5. As can be seen here, the Chi-Square value $(1,380.03)$ is statistically significant at 0.01 significance level. However, as can be stated above, Chi-Square alone is not sufficient. For that reason, the values which present the compliance of the model and are generally accepted are X2 / df, GFI, CFI, IFI, RMR and RMSEA values. Since there is no exact consensus in the literature about which one of this goodness of fit values is regarded, these values are evaluated by their handling as a whole. These values are also presented together in Table 5 in this study.

Table: 5

Goodness of Fit Values Between Data and Model

\begin{tabular}{|c|c|c|c|}
\hline Cohesion Criterion & Abbreviations & Research Model & Reference Values \\
\hline $\mathrm{X}^{2}$ Value & CMIN & 331.10 & ---------- \\
\hline Degree of Freedom & $\mathrm{DF}$ & 160 & \begin{tabular}{|c|c|}
$-\cdots----$ \\
\end{tabular} \\
\hline $\mathrm{P}$ & $\mathrm{P}$ & 0.000 & \\
\hline $\mathrm{X}^{2} / \mathrm{df}$ & CMIN/DF & 2.07 & $\begin{array}{l}>5 \text { Admissible } \\
>2 \text { Decent }\end{array}$ \\
\hline Goodness of Fit Index & GFI & 0.92 & $\geq 0.90$ \\
\hline Corrected Goodness of Fit Index & AGFI & 0.90 & $\geq 0.90$ \\
\hline Incremental Goodness of Fit Index & IFI & 0.83 & 1.000 \\
\hline Compare Goodness of Fit Index & CFI & 0.83 & 1.000 \\
\hline Root Mean Square Error of Approximation & RMSEA & 0.053 & $0.05<$ RMSEA $<0.08$ \\
\hline Surplus Ratio Square Root & RMR & 0.089 & $0.05<$ RMR $<0.08$ \\
\hline
\end{tabular}

In this context, when Table 5 is analysed, it is observed that $\chi 2 / \mathrm{df}=2.07$; $\mathrm{RMR}=0.089$; $\mathrm{GFI}=0.90 ; \mathrm{IFI}=0.83$; $\mathrm{CFI}=0.83$; and $\mathrm{RMSEA}=0.053$. When the related values are evaluated within the frame of an ideal model, it can be said that the model complies well. 
In this context, the validity of descriptive factor analysis and the found internal audit perception scale were also confirmed with confirmatory factor analysis.

\subsection{Findings}

In structural equation modelling after the model and the data compliance were tested, the relationship between the variables was analysed. In this analysis the direct and indirect effects of a variable on another variable or variables were investigated.

$\mathrm{T}$ and $\mathrm{R}^{2}$ values belonging to the observed variables determining the implicit variables are presented in Table $6 . \mathrm{T}$ value in the table is found by dividing the estimation value by the standard error. The $t$ value is expected to be higher than 1.96 so that the obtained regression coefficient can be found significant (Schumacker \& Lomax, 2004). Since the $t$ value of all other factors apart from the management support perception is higher than 1.96 when the calculated parameter values (the values belonging to the paths from the implicit variables to the observed variables) are analysed in our model, it is considered to be sufficient to analyse the structural model. Accordingly:

It was observed that the independence implicit variable is most clarified by the $\mathrm{I} 2$ and I2 observed variables; the neutrality implicit variable is most clarified by the N1 and N4 observed variables; the administrational support implicit variable is most clarified by the YS2 observed variable; and the Value Added implicit variable is most clarified by the VA3 observed variable. However, the external variable called Internal Audit Perception is observed to be clarified by the IA3 observed variable the most.

Table: 6

\section{Measurement Model Results}

\begin{tabular}{|c|c|c|}
\hline Factor / Substance & $\begin{array}{l}\text { Stand. } \\
\text { Loads }\end{array}$ & $\begin{array}{c}\text { t - } \\
\text { Value }\end{array}$ \\
\hline \multicolumn{3}{|l|}{ Perception of Independence } \\
\hline $\begin{array}{l}\mathrm{I} 1=\mathrm{I} \text { think that the internal audit personnel in our institution are sufficiently independent from the senior management to fulfil } \\
\text { their professional obligations and duties. }\end{array}$ & 0.70 & 8.99 \\
\hline $\begin{array}{l}\mathrm{I} 2=\text { The internal audit staff at our institution can easily access all departments and employees within the scope of internal } \\
\text { audit activities. }\end{array}$ & 0.40 & 6.09 \\
\hline I3= The internal auditors in our institution are rarely interfered with by management when conducting their business. & 0.35 & 5.41 \\
\hline I4= I believe that the internal auditors working in our institution are oppressed by the people they work under. & 0.23 & 3.58 \\
\hline \multicolumn{3}{|l|}{ Perception of Objectivity } \\
\hline $\mathrm{N} 1=\mathrm{I}$ think that the internal audit personnel working in our institution act with objectivity. & 0.52 & 7.67 \\
\hline $\begin{array}{l}\mathrm{N} 2=\text { I think that the internal audit personnel working in our institution have formed their opinions without being affected by } \\
\text { the thoughts and suggestions of others. }\end{array}$ & 0.48 & 7.19 \\
\hline $\begin{array}{l}\mathrm{N} 3=\text { I think that the internal audit staff can provide information directly to the chief audit executive when faced with a situation } \\
\text { that affects their neutrality. }\end{array}$ & 0.47 & 7.06 \\
\hline $\begin{array}{l}\text { N4= I believe that the internal audit staff working in our institution have made decisions in their work without their own } \\
\text { convictions and prejudices. }\end{array}$ & 0.50 & 7.40 \\
\hline \multicolumn{3}{|l|}{ Top Management Support Perception } \\
\hline MS1= I think that the top management in our institution cares enough about the internal audit institution. & 0.53 & 9.45 \\
\hline MS2= It provides sufficient support to the internal auditors for fulfilling their duties and responsibilities. & 0.67 & 12.13 \\
\hline $\begin{array}{l}\text { MS3= I believe that the top management in our institution fully considers the internal audit reports in the conduct of the } \\
\text { business. }\end{array}$ & 0.67 & 12.07 \\
\hline $\begin{array}{l}\text { MS4= I think that the senior management in our institution has taken the necessary measures to protect the independence and } \\
\text { neutrality of internal audits. }\end{array}$ & 0.58 & 10.39 \\
\hline \multicolumn{3}{|l|}{ Perception of Value Added to the Institution } \\
\hline $\begin{array}{l}\text { VA1= I can say that the internal audit organization in our institution has made significant contributions to the organization's } \\
\text { strategic goals. }\end{array}$ & 0.47 & 8.02 \\
\hline $\begin{array}{l}\text { VA2= I think that the internal audit organization in our institution has an important share in acting in accordance with the } \\
\text { objectives of the organization. }\end{array}$ & 0.48 & 8.14 \\
\hline
\end{tabular}




\begin{tabular}{|l|c|c|}
\hline VA3= I believe that the internal audit organization in our institution contributes to the efficiency of the institution. & 0.69 & 11.64 \\
\hline $\begin{array}{l}\text { VA4= I believe that the internal auditing in our institution increases effectiveness by providing independent advice on } \\
\text { financial matters to corporate managers. }\end{array}$ & 8.60 \\
\hline Internal Audit Perception & 0.51 & 0.35 \\
\hline IA1= I consider internal auditing to be a beneficiary of all public institutions. & 0.57 & 5.15 \\
\hline IA2= I think internal auditing plays an important role in improving the performance of public institutions. & 5.23 \\
\hline $\begin{array}{l}\text { IA3= I underestimate public institutions which lack the internal audit system in terms of internal accounting and internal } \\
\text { control systems. }\end{array}$ & 0.61 & 5.08 \\
\hline $\begin{array}{l}\text { IA4= I think that public institutions that lack internal audit systems cannot use public resources effectively, economically and } \\
\text { efficiently. }\end{array}$ & 0.55 & 5.56 \\
\hline
\end{tabular}

After the model and data compliance are tested, the relationships between variables are analysed in structural equation modelling analyses. In order to present these relationships between the variables, path diagrams can be used. Here, an equation which indicates the relationship between independent and dependent variables is obtained.

Figure: 2

\section{Path Diagrams Standardized for the Research Model}

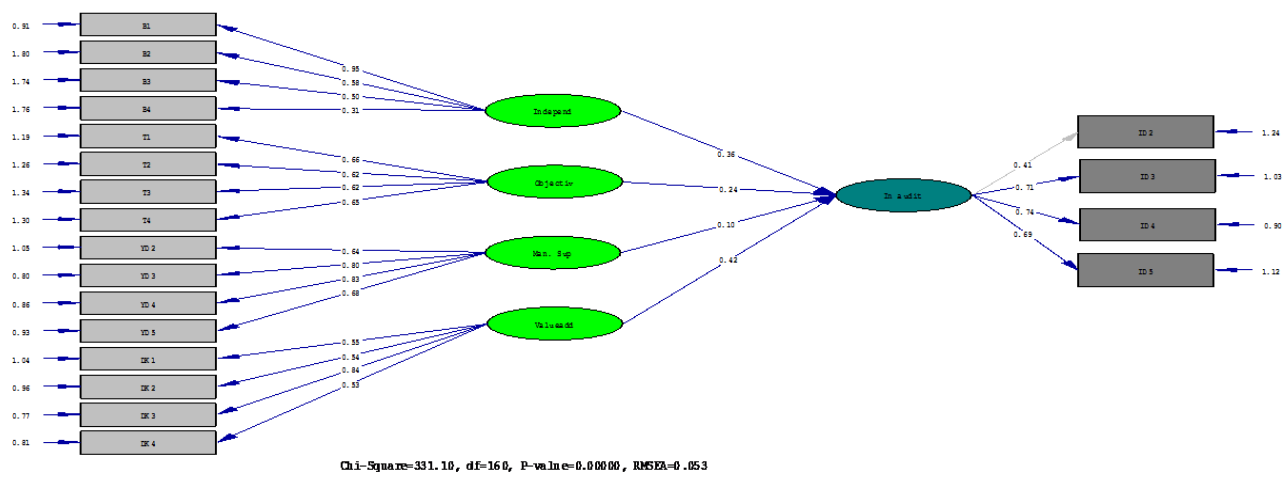

The display of the tested model on the LISREL 8.51 package program is presented in Figure 2. The path diagrams in Figure 2 were obtained in order to test the model. The criteria used in interpreting the standardized paths are as follows. It indicates that the degree of support of the hypotheses is low when the values of the standardized loads are around 0.10 and high when they are medium and over 0.50 . We can see that all of the standardized paths in this figure are statistically significant. 
Figure: 3

\section{Structural Model Standardized Road Coefficients}

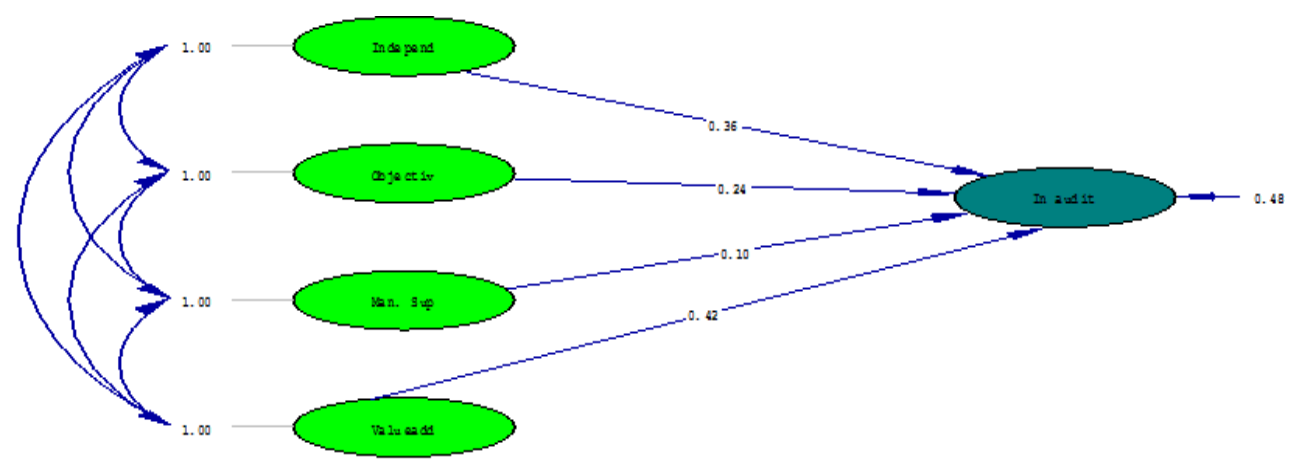

Ghi-5quare=331.16, df=168, P-valne=

As can be understood from the figure that standardized loads of our external implicit variable called Internal Audit Perception to clarify "Independence, Neutrality, Top Management Support and Added Value to Institution" internal implicit variables are found $(0.36 / 0.24 / 0.10$ and 0.42$)$ respectively.

Table: 7

Test Results of Hypotheses in the Model

\begin{tabular}{|c|c|c|c|}
\hline Hypotheses & $\begin{array}{l}\text { Hypotheses } \\
\text { Heading }\end{array}$ & $\begin{array}{c}\text { Standardized } \\
\text { Solution }\end{array}$ & Result \\
\hline H1. An effective internal audit depends on a high degree of independence. & + & 0.36 & Supported \\
\hline H2. An effective internal audit depends on a high level of neutrality. & + & 0.24 & Supported \\
\hline $\begin{array}{l}\text { H3. An effective internal audit depends on the level of support that senior management provides to the } \\
\text { internal audit unit. }\end{array}$ & + & 0.10 & Meaningless \\
\hline $\begin{array}{l}\text { H4. An effective internal audit depends on the level of value the internal audit unit adds to the } \\
\text { organization. }\end{array}$ & + & 0.42 & Supported \\
\hline
\end{tabular}

In the study, Figure 3 and Table 7 were prepared to evaluate the direction of the hypotheses in our model and the standardized solution values. According to the data:

Our first hypothesis is that the relationship between the criteria of Independence and Internal Audit Perception is positive. After testing the model, it was identified that this effect was +0.36 . Positive and significant standardized values indicated that internal audit perceptions of public officials having financial liabilities in public administrations were high although they had attitudes indicating that the internal audit was not independent. In this context, it was concluded that there was a positive relationship between the belief in the independence of internal audits and internal auditing perception. 
Our hypothesis is that the relationship between the criteria of Neutrality and Internal Audit Perception is positive. After testing the model, it was identified that this effect was +0.24 . Since the standardized value was positive, the hypothesis was confirmed. Our hypothesis is that the relationship between the criteria of Administrational Support and Internal Audit Perception is positive. After testing the model, it was identified that this effect was +0.10 . Although the standardized value was found to be positive, the t-value was less than 1.96 and the path diagram was meaningless. Our hypothesis is that the relationship between the criteria of Added Value and Internal Audit Perception is positive. After testing the model, it was identified that this effect was +0.42 . Positive and significant standardized value indicates that the criterion of added value has a great effect on Internal Audit Perception.

\section{Conclusion and Recommendations}

The relationships between the criteria of Independence, Neutrality, Administrational Support and Added Value as functions of internal auditing, with public officials' perceptions of internal audits with financial liabilities, was analysed through the model established within the scope of this study. In this context, this study also helps us understand the perception level of the factors which are necessary for the quality and efficiency of internal audit.

Of course, this study has some methodological limitations. For instance, the fact that this study is based on data obtained from a survey, and the possibility that financial officials in public administrations answered the survey questions thinking of their own institutions and refraining from the executives, are also regarded by us as concerns. In addition, the possibility that the answers of executives and spending authorities are prejudiced is thought to be another concern. However, it is important to indicate the effect of the factors necessary for effective internal auditing and to provide a different perspective for future studies although we have these concerns.

When we look at the relationship between internal audit's criteria of added value to the institution and the perception of internal audit, a positive and strong relationship was identified in parallel to the established hypothesis. Accordingly, it was observed that among the factors needed for an effective internal audit, the highest perception by public officials with financial liabilities was to add value to the institution. In other words, it was observed that high added value perception from internal audits was the most influential factor for internal auditing. After all, one of the most important purposes for internal audit activities is to create both financial and administrational added value to public institutions by providing insurance and consultancy service to the institutional administration and therefore help public institutions reach their goals. With the function of providing added value to the institution, we can argue that internal auditing can affect the scope, direction, and quality.

As a result, internal auditing should initially have an independent working atmosphere so that the internal audit, which does not have an effective structure in Turkey, may reach the desired point (as a result of the findings we obtained). Creating the perception 
in public officials with financial liabilities that internal audit is carried out independently should be considered an important step for an effective internal audit. In addition, emphasizing the element of adding value and providing internal auditors with professional competence to organize neutrally and especially by obtaining the support of executives should be considered the essential components of an effective internal audit. Also, another critical point for internal audit systems of public institutions is executive support. The data we obtained in the study highlights the importance of this issue. In our study, we can see that the perception of public officials with financial liabilities regarding executives is low (0.10). This indicates that financial officials' perception that internal auditing is supported by executives is low. Therefore, if we want to discuss an effective internal audit in public institutions, it would be advantageous for executives to provide internal auditors with enhanced powers, so that the internal audit unit can fulfil their duties and responsibilities by ensuring support for internal audit and auditors.

\section{References}

Ahmad, H. \& R. Othman \& K. Jusoff (2009), "The Effectiveness of Internal Audit in Malaysian Public Sector", Journal of Modern Accounting and Auditing, 5(9), 53-62.

Aikins, S.K. (2011), “An Examination of GovernmentInternal Audits’ Role in Improving Financial Performance", Management, 11(4), 306-337.

Akçay, S. (2013), “Türkiye’de İç Denetim Sürecinin Kamu Kurumlarının Faaliyet Sonuçları Üzerindeki Etkinliği: Belediyeler Üzerine Bir Uygulama”, Afyon Kocatepe Üniversitesi IIIBF Dergisi, XV(I), 57-77.

Akyel, R. (2010), “Türkiye'de İç Kontrol Kavramı, Unsurları Ve Etkinliğinin Değerlendirilmesi”, Yönetim ve Ekonomi: Celal Bayar Üniversitesi İktisadi ve İdari Bilimler Fakültesi Dergisi, 17(1), 83-97.

Arslan, B. (2010), "Bir Yönetim Fonksiyonu Olarak İç Denetim”, Sayıştay Dergisi, 77, 63-86.

Başpınar, A. (2006), "Kamuda İç Denetim ve Merkezi Uyumlaştırma Fonksiyonu”, Maliye Dergisi, $151,23-42$.

Bayar, D. (2008), “Mali Denetim Nedir”, Maliye Dergisi, 155, 1-10.

Bozkurt, M. (2010), "İyi Mali Yönetimin Gerçekleştirilmesinde İç Kontrol ve Denetimi”, SAYDER Dış Denetim Dergisi, 1, 129-136.

Brierley, J.A. \& H.M. El-Nafabi \& D.R. Gwilliam (2001), “The Problems of Establishing Internal Audit in the Sudanese Public Sector", International Journal of Auditing, 5(1), 73-87.

Çalış, Y.E. (2013), Aracı Kurumlarda İç Denetim Uygulaması, Yalın Yayıncılık, İstanbul.

Carcello, J.V. \& D.R. Hermanson \& K. Raghunandan (2005), "Factors Associated with US Public Companies' Investment in Internal Auditing", Accounting Horizons, 19(2), 69-84.

Clark, M. \& T. Gibbs \& R. Shroeder (1981), “CPA's Judge Internal Audit Department Objectivity”, Management Accounting, 62, 40-43.

Cohen. A \& G. Sayag (2010), "The Effectiveness of Internal Auditing: An EmpiricalExamination of its Determinants in Israeli Organisations", Australian Accounting Review, No. 54, 20(3), 296-307. 
Enofe, A.O. \& C.J. Mgbame \& V.E. Osa-Erhabor \& A.J. Ehiorobo (2013), “The Role of Internal Audit in Effective Management in Public Sector", Research Journal of Finance and Accounting, 4(6), 162-168.

Fernandez, S. \& H.G. Rainey (2006), "Managing Successful Organizational Change in the Public Sector", Public Admin Rev., 66, 168-176.

Getiemihret, D. \& A. Wondimyismaw (2007), "Internal Audit Effectiveness: an Ethiopian Public Sector Case Study", Managerial Auditing Journal, 22(5), 470-484.

Gönülaçar, Ş. (2007), “İç Denetimde Hedefler ve Beklentiler (II)”, Mali Hukuk Dergisi, 22(131), 4247.

Gürkan, N.Z. (2009), “Türk Kamu Mali Yönetiminde İç Denetim ve İç Denetim Algısı”, Süleyman Demirel Üniversitesi Sosyal Bilimler Enstitüsü Maliye Anabilim Dalı, Yüksek Lisans Tezi, Isparta.

Guthrie, J. \& L. English (1997), "Performance Information and Programme Evaluation in the Australian Public Sector”, International Journal of Public Sector Management, 10(3), 154-164.

Hair, J.F. \& R.E. Anderson \& R.L. Tatham \& W.C. Black (2009), Multivariate Data Analysis, PrenticeHall, New Jersey.

Institute of Internal Auditors (IIA) (2011), Independence and Objectivity, <https://www.iia.org.uk/media/57156/independence_and_objectivity.pdf〉, 23.07.2017.

Kaya, K. (2016), “Kamu Kurumlarında İç Denetim ve Bir Anket Uygulaması”, Başkent Üniversitesi Sosyal Bilimler Enstitüsü İşletme Anabilim Dalı, Yüksek Lisans Tezi, Ankara.

Kızılboğa, R. (2013), “İç Denetim Sisteminde Denetçilerin Bağımsızlık ve Tarafsızlığının Önemi”, Marmara Üniversitesi Siyasal Bilimler Dergisi, I(I), 107-119.

Koçak, S.Y. \& T. Kavakoğlu (2010), "İl Özel İdarelerinde İç Denetim Sisteminin Değerlendirilmesine İlişkin Bir Araştırma”, Sayıştay Dergisi, 77, 119-148.

Kolçak, M. (2006), "Kamu Mali Yönetimi ve Kontrol Kanununun Türk Mali Sistemine Getirdikleri (5436 Sayılı Kanun Değişiklikleriyle)”, Atatürk Üniversitesi Sosyal Bilimler Enstitüsü Dergisi, 7(1), 367-384.

Korkmaz, U. (2007), "Kamuda İç Denetim”, Bütçe Dünyası, 2(25), 4-15.

Kuluçlu, E. (2006), "Yönetimin Denetiminden Denetimin Yönetimine”, Saylştay Dergisi, 63, 3-37.

Leung, P. \& B.J. Cooper \& P. Robertson (2004), The Role of InternalAudit in CorporateGovernance and Management, RMIT Publishing, Melbourne.

Memiş, M.Ü. (2008), “Etkin ve Başarılı Bir İç Denetim İçin Gerekli Koşullar”, Mali Çözüm Dergisi, $85,75-91$.

Mutchler, J.F. ( 2001), Independence and Objectivity: A Framework forResearchOpportunities in Internal Auditing, The Institute of Internal Auditors Research Foundation, London.

Okur, Y. (2010), “Türkiye'de Teftiş ve İç Denetim: Kavramlar, Beklentiler ve Hayatla Yüzleşme”, Maliye Dergisi, 158, 570-586.

Şahin, Ü. (2008), “5018 Sayılı Kamu Mali Yönetimi ve Kontrol Kanununda İç Denetim Sistemi”, Karamanoğlu Mehmetbey Üniversitesi Sosyal ve Ekonomik Araştırmalar Dergisi, 2, 289302.

Schumacker, R.E \& R.G. Lomax (2004), A Beginner's Guide to StructuralEquationModeling, $2^{\text {nd }}$ ed., Lawrence Erlbaum Associates Inc. Publishers, Londra. 
Sterck, M. \& G. Bouckaert (2006), "International Audit Trends in the Public Sector: A Comparison of Internal Audit Functions in the Governments of Six OECD Countries Finds Similarities in Legal Requirements, Organizational Structure, and Future Challenges" Internal Auditor, 63(4), 49-53.

Subramaniam, N. \& C. Ng \& P. Carey (2004), "Outsourcing Internal Audit Services: An Empirical Study on Queensland Public-Sectorentities", Australian Accounting Review, 14(34), 8695.

Sümer, N. (2000), "Yapısal Eşitlik Modelleri”, Türk Psikoloji Yazıları, 3(6), 49-74.

Tabak, A. \& A. Erkuş (2014), "Denetim Odağının Bireylerin Belirsizlikle Baş Etme Düzeylerine Etkisi: Kamu Sektöründe Bir Araştırma”, Hacettepe Üniversitesi İktisadi ve İdari Bilimler Fakültesi Dergisi, 26(1), 213-227.

Udeh, S.N. \& E.O. Nwadialor (2016), "Evaluation of Effectiveness of Internal Audit in the Nigerian Public Sector", European Journal of Business, Economics and Accountancy, 4(3), 44-58.

Uzun, A.K. (2009), "Kamu Yönetiminde İç Kontrol Ve İç Denetim Yaklaşımı”, Denetişim, Kamu İç Denetçileri Derneği Yayını, 3, 59-65.

Van Gansberghe, C. (2005), "Internal Auditing in the Public Sector: A Consultative Forum in Nairobi, Kenya, Shoresup Best Practices for Government Audit Professionals in Developing Nations", Internal Auditor, 62(4), 69-73.

Van Peursem, K.A. (2005), "Conversations with Internal Auditors - the Power of Ambiguity", Managerial Auditing Journal, 5, 489-512. 